Problems of World Agriculture volume 18 (XXXIII), number 4, 2018: 359-369 DOI: $10.22630 /$ PRS.2018.18.4.125

Robert Nowacki $^{1}$, Katarzyna Wasilik ${ }^{2}$

${ }^{1}$ University of Economics and Human Sciences in Warsaw, Poland

${ }^{2}$ Polish Economic Institute in Warsaw, Poland

\title{
Cooperation of Enterprises of the Sector of Food Processing Industry with the Entities Rendering Business Services
}

\begin{abstract}
An intensive competition in the sector of food processing industry sets forth the requirement of improving the processes of operating in the market. One of them is cooperation with the entities rendering business services. The aim of the paper is to analyse the level of making use of business services by the enterprises operating in the food processing industry as well as to assess the cooperation between the companies rendering such services. The authors used for this purpose the results of quantitative research carried out among the enterprises operating in the polish market. In result of thereof they have ascertained that, in general, along with the growth of the size of an enterprise there grows the scale of the use of business services, and it must be said that greater propensity to use business services is displayed by the enterprises with the share of foreign capital. At the same time, the assessment of cooperation with the companies rendering business services is not determined either by the size of an enterprise or by the share of foreign capital.
\end{abstract}

Key words: food processing industry, business services, cooperation of enterprises, business relations

JEL Classification: L66, L84, P13

\section{Introduction}

The enterprises operating in the modern economy constantly look for the solutions that would have allowed building their competitive edge and would have been a base for a market success. The key strategic value for the companies operating on the B2B principles is an ability to set forth and manage interpersonal relationships understood as interplay of business partners with a simultaneous experiencing that interplay (Rogoziński, 2006). The exchange based on partner relationships means the process where partners form bonds of the social, economic and technical nature whose aim is to reduce the transaction costs and to increase the delivered value leading to mutual benefits (Zieliński, 2014). An extensive research in the B2B environment has shown the pivotal importance of relationships for carrying out business activity (Leszczyński, 2012). The formation and maintenance of external relationships is seen as the sources for not only survival, but also for the development of contemporary organisations (Dyer et al., 1998; Vaan, 2014; Krupski, 2015). The external relationships may make up the basic source of an above-average value and competitive edge (Niemczyk, 2015; Czakon, 2005), often determining the market position of enterprises and their effectiveness (Stańczyk-Hugiet et al., 2015; Klimas, 2015).

It is generally assumed that the contemporary world of business requires from the management practice effectiveness in the sphere of formation and maintenance of various

\footnotetext{
${ }^{1} \mathrm{PhD}$, University of Economics and Human Sciences in Warsaw, ul. Pawia 55, 01-030 Warszawa, e-mail: nowacki@vizja.pl,https://orcid.org/0000-0001-7380-0672

${ }^{2} \mathrm{PhD}$, Polish Economic Institute in Warsaw, Al. Jerozolimskie 87, 02-001 Warszawa,

e-mail: katarzyna.wasilik@wp.pl, https://orcid.org/0000-0002-7729-3644
} 
types of relationships and even entire networks of external relationships (Ritter et al., 2004). As the research shows, the enterprises interested in their long-term functioning, all the more the enterprises oriented on the development and improvement of their competitive position, must retain various external relationships: business and non-business, formal and informal, interorganisational and interpersonal (Ritter, 1999). The importance of retention of relationships is the bigger the bigger is their dynamics, complexity or uncertainty of the market environment (Krupski, 2015).

The above-mentioned phenomena concern all enterprises operating in the market, also those functioning in the sector of food processing industry. The food processing industry is one of the most important and the fastest-growing branches of the Polish economy. In 2017, the average employment amounted to 402.7 thousand workers, what accounted for $15.2 \%$ of all employees working in industry. The sales value in 2017 amounted to 244.26 billion zlotys, what accounted for the $18 \%$ share in the industrial sector (Industry..., 2018).

Against that background, there can be clearly seen the legitimacy of undertaking research related to identification of the scale of use of business services by the enterprises belonging to the sector of food processing industry. These topics has yet been lacking of a thorough analysis in the literature. The described surveys most often concern the use of business services in the context of enterprises as the whole. There are also lacking studies related to assessment of cooperation with the entities rendering these services. This specific gap in knowledge has been a cause for undertaking by the authors the research on the issues in question.

The aim of the article is to analyse the level of the use of business services by the enterprises operating in the food processing industry as well as to assess cooperation between the companies rendering such services. The authors focused on the identification and assessment of dependences between the issues in question and the two features of enterprises: the size measured by the number of employees and the capital origin. To evaluate these dependences the authors used, besides the descriptive statistics, the tests: Pearson's $\chi^{2}$ Test, Mann-Whitney U Test, and ANOVA (Kruskal-Wallis) Test. The grounds for considerations were the results of quantitative research carried out in the years 20142015 among enterprises of the sector of food processing industry.

\section{The role of business services in the contemporary world - theoretical framework}

Among the service activities, in the recent years, there has been observed the dynamic development of the market for services connected with business support activities, commonly called business services (Internal Market, 2015). Business services are connected with business and enterprise support activities, being complementary thereto (Nowacki, 2009). They comprise all services rendered by specialised firms on behalf of other entities in order to increase their effectiveness, productivity and competitiveness (Kuczewska, 2009). Business services comprise diversified types of activity, from simple activities requiring solely manual qualifications and undergoing standardisation (e.g. cleaning, property protection) till the services involving employees with a very high level of competency, taking the form of individual projects (e.g. legal services, economic consulting, scientific research, etc.). However, all types of services, being a part of business services, have one common denominator - recipients thereof are business entities. 
In their article, the authors adopted the definition of the Central Statistical Office, according to which business services mean "an aggregate of services rendered by specialised companies on behalf of other establishments in order to increase their effectiveness, productivity and competitiveness" (Internal Market, 1997). This definition aptly expresses the essence of business services as there is emphasised in it their importance in raising business entities' competitiveness. Among sparse definitions accessible in publications, it is proper to mention another one, in accordance with which business services are "all services related to enterprising and enterprise servicing" (Chilimoniuk-Przeździecka, 2011). The term 'business services' is often substituted by the designation 'professional services' (Rogoziński, 2000).

The entities rendering business services include enterprises running, inter alia, their activities within the framework of telecommunication, IT, information, legal, accounting and bookkeeping, and tax-consulting services, in the field of management and consulting, R\&D, engineering and architectonic, advertising services, market and public opinion research as well as those related to employment. These are the so-called smart business services or knowledge-saturated services (Kox, Rubalcaba, 2007), intrinsically being characterised by high innovativeness, what stems from the development of the accompanying infrastructure and the required creativity (Nowacki, 2016).

The economic importance of business services must be considered both in the macroand microeconomic scale. Their macroeconomic role is primarily expressed in actuating the development of the economy and in raising the level of its competitiveness. In the economic system, they also play the innovative, value-creating, canvassing, supporting, and information roles (Majchrzak, 2012; Daszkowska, 1998). In the microeconomic scale, business services are the driving force of the development of entrepreneurship. The expediency of their use results from the determinants of costs, time and place. Use of business services provides the enterprise with cost reduction, enables focusing on their basic activity, is conducive to the increase of enterprise's goodwill and to the growth of competitiveness as well as ensured the access to new technologies (Dąbrowska, 2008). An enterprise can fulfil many functions on its own or to commission execution thereof to other companies. The services provided by professional firms are, as a rule, not only cheaper (owing to the use of the economies of scale) than those performed on their own, but also of a higher quality (the effect of specialisation). The decision on outsourcing may be a result of the conviction that specialised service companies have deep professional knowledge in various disciplines, unique expertise in the field of recipients, and methods of formation of their behaviours; finally, they have a significantly greater creative potential, owing to which they can contribute to better business effects of their customers (Gralpois, Liodice, 2010). The sector of business services is also a source of innovation for enterprises as well as affects effectiveness of their activity (Szczukocka, 2012).

Pursuant to the CSO's data, in 2016, in the domestic market, there were operating approx. 444 thousand enterprises which, within the framework of their basic activities, rendered business services. Those enterprises accounted for $26.2 \%$ out of almost 1.7 million enterprises running their economic activity. Compared to the previous year, the number of those enterprises increased by $11.4 \%$, whereas the number of the whole body of enterprises running their economic activity grew by $5.5 \%$. In 2016, in the sector of business services, there were working more than 1.5 million people, i.e. $17.3 \%$ of workers at enterprises as the whole. Vis-à-vis 2015, the number of employees in this sector grew by $7.8 \%$ compared to the $4.1 \%$ growth in the number of employees at enterprises as the whole. 
Sales of enterprises classified to the service branches related to business support activities reached 308.8 billion zlotys, what accounted for $7.7 \%$ of the value of sales of enterprises running business as the whole. Compared to the previous year, the sales value grew by $5.4 \%$ (in the sector of enterprises as the whole, there was noted the growth by $4.2 \%$ ) (Business Services, 2018).

\section{The data and research method}

The basis for the study is results of the research carried out in 2014-2015 within the framework of the project related to an analysis of business services at enterprises operating in the Polish market. The research was carried out within the project financed by the National Science Centre No. 2013/09/B/HS4/02733, entitled Innovativeness of Business Services in Raising Enterprises' Competitiveness. A Model Approach on the nation-wide quota stratified sample of 505 entities with the number of employees exceeding 9 persons; among them, 201 entities represented the sector of food processing industry. In the sampling process, there were taken into account the three stratifying variables: the sector of operation, the size measured with the number of employees, and locality of headquarters. To describe the surveyed population there were also used the variables connected with the range of activity, the year of emergence, the market position, economic situation, monthly turnover, and the capital origin (Kuczewska, Nowacki, 2016). The structure of the surveyed sample of enterprises belonging to the sector of food processing industry, from the point of the two features analysed in this article (the enterprise's size and capital origin), is presented in Table 1.

Table 1. Structure of the surveyed sample of enterprises of the sector of food processing industry

\begin{tabular}{ll|cc}
\hline \multicolumn{2}{c|}{ Enterprises' features } & N & $\%$ \\
\hline Number of employees & from 10 to 49 & 32 & 15.9 \\
& from 50 to 249 & 75 & 37.3 \\
& 250 and more people & 94 & 46.8 \\
Capital origin & exclusively Polish & 149 & 74.1 \\
& foreign or mixed & 52 & 25.9 \\
\hline
\end{tabular}

Source: own research, 2014/2015.

The survey was carried out by the method of face-to-face interviews based on the author's questionnaire. In the context of this paper, the authors attempted in their research to answer the two research questions:

- Does the use of business services depend on the enterprise's size and capital origin?

- Do the enterprise's size and capital origin differentiate assessment of the cooperation with the firms rendering business services?

The research questions posed in the article lead to the formulation of the following four hypotheses:

- H1: there occurs a statistically significant correlation between the size of an enterprise and the use of business services; 
- H2: there occurs a statistically significant correlation between the origin of capital, and the use of business services;

- H3: there occurs no statistically significant correlation between the size of an enterprise and evaluation of cooperation with companies providing business services;

- H4: there occurs no statistically significant correlation between the origin of the capital of an enterprise and evaluation of cooperation with companies providing business services.

The analyses findings are presented taking into consideration the differentiation into the two basic categories of enterprises: their size and capital origin. The findings analysis was carried out with the use of the statistical package IBM SPSS Statistics 24.0. For the purpose of presentation of the scale of use of business services, there were applied the indices of structure, whereas in order to show the assessments of cooperation with service companies there were used the average values and standard deviation. The relationships between the independent (exogenous) variables and the dependent (endogenous) variables are determined on the base of nonparametric tests: $\chi^{2}$ Pearson's test (in case of the relationships between the use of business services and the enterprise's size and its capital origin), the Mann-Whitney test (in case of the relationship between the assessment of cooperation and the capital origin), and the ANOVA Kruskal-Wallis test (in case of the relationship between the assessment of cooperation and the enterprise's size), at a critical level of significance of $p=0.05$. To determine the strength of relationship between the use of business services and the enterprises' features there was applied the Cramer's V test.

\section{Results}

\section{Use of business services by enterprises from the sector of food processing industry}

The carried out research shows that the enterprises belonging to the sector of food processing industry relatively often make use of business services, though the scale and range of use of individual categories of services is diversified. Definitely most often - by all the entities surveyed - are used telecommunication services. The often used business services include also those related to software and consultancy in the field of computer science $(74.6 \%)$ as well as accounting and bookkeeping, and tax consulting services $(72.6 \%)$, followed by legal services $(67.2 \%)$. More than one half of enterprises also declare the use of information services $(59.2 \%)$ and advertising ones $(55.2 \%)$. Other services are used more seldom, by less than every second enterprise (Table 2).

In case of the majority of services, one may notice the positive dependence between the use thereof and the enterprises' size - the bigger they are the more often they make use of business services. The biggest differences occur in case of the services related to information, management and consulting as well as R\&D (by approx. 30 p.p.). The exceptions are accounting and bookkeeping services, advertising ones and those related to employment. The first are most frequently used by small entities (as it is more profitable to outsource them than to keep one's own accountancy). In case of the second, the scale of use at small and big enterprises is approximate. In turn, the third are used most often by the biggest entities, while the most seldom medium ones (it is alike in case of advertising and accounting and bookkeeping services). In case of the profile related to the capital origin, in case of all business services (naturally, apart 


\section{R. Nowacki, K. Wasilik}

from telecommunication ones), there occurs a greater propensity to make use of them in the entities with foreign capital or mixed one. The biggest disparities of the structure-related indices occur in case of the services related to $R \& D$ (the difference is as much as 38.7 p.p.) as well as to advice and consulting services, market and public opinion research, and information services (the differences amounting to more than 20 p.p.). In turn, the least disparities are specific to the services related to software and computer sciences as well as accounting and bookkeeping services (nearly 6 p.p.).

Table 2. Use of business services at the surveyed enterprises from the sector of food processing industry

\begin{tabular}{|c|c|c|c|c|c|c|}
\hline \multirow[b]{2}{*}{ Services } & \multirow[b]{2}{*}{ Total } & \multicolumn{3}{|c|}{ Size of the enterprise } & \multicolumn{2}{|c|}{ Capital origin } \\
\hline & & Small & Medium & Large & $\begin{array}{l}\text { Purely } \\
\text { Polish }\end{array}$ & $\begin{array}{l}\text { Foreign and } \\
\text { mixed }\end{array}$ \\
\hline Telecommunication & $100.0 \%$ & $100.0 \%$ & $100.0 \%$ & $100.0 \%$ & $100.0 \%$ & $100.0 \%$ \\
\hline $\begin{array}{l}\text { Those related to software } \\
\text { and IT consultancy }\end{array}$ & $74.6 \%$ & $56.3 \%$ & $74.7 \%$ & $80.9 \%$ & $73.2 \%$ & $78.8 \%$ \\
\hline Information & $59.2 \%$ & $37.5 \%$ & $57.3 \%$ & $68.1 \%$ & $53.7 \%$ & $75.0 \%$ \\
\hline Legal & $67.2 \%$ & $53.1 \%$ & $58.7 \%$ & $78.7 \%$ & $63.1 \%$ & $78.8 \%$ \\
\hline $\begin{array}{l}\text { Accounting and book- } \\
\text { keeping/tax consulting }\end{array}$ & $72.6 \%$ & $87.5 \%$ & $64.0 \%$ & $74.5 \%$ & $71.1 \%$ & $76.9 \%$ \\
\hline $\begin{array}{l}\text { Consultancy related to } \\
\text { management/consulting }\end{array}$ & $36.8 \%$ & $15.6 \%$ & $33.3 \%$ & $46.8 \%$ & $29.5 \%$ & $57.7 \%$ \\
\hline In the field of R\&D & $32.8 \%$ & $12.5 \%$ & $22.7 \%$ & $47.9 \%$ & $22.8 \%$ & $61.5 \%$ \\
\hline Advertising & $55.2 \%$ & $59.4 \%$ & $46.7 \%$ & $60.6 \%$ & $51.7 \%$ & $65.4 \%$ \\
\hline $\begin{array}{l}\text { Market and opinion } \\
\text { research }\end{array}$ & $24.4 \%$ & $12.5 \%$ & $14.7 \%$ & $36.2 \%$ & $18.1 \%$ & $42.3 \%$ \\
\hline Related to employment & $44.8 \%$ & $40.6 \%$ & $33.3 \%$ & $55.3 \%$ & $40.3 \%$ & $57.7 \%$ \\
\hline
\end{tabular}

Source: own research, 2014/2015.

Table 3. Assessment of statistical significance between the use of business services and the size and capital origin of the enterprises surveyed from the sector of food processing industry with the $\chi^{2}$ test

\begin{tabular}{|c|c|c|c|c|c|c|}
\hline \multirow[b]{2}{*}{ Services } & \multicolumn{3}{|c|}{ Size of the enterprise } & \multicolumn{3}{|c|}{ Capital origin } \\
\hline & $\begin{array}{c}\text { Test's } \\
\text { value } \\
\chi^{2}\end{array}$ & $\begin{array}{l}\text { Signifi- } \\
\text { cance } \\
\mathrm{p}\end{array}$ & $\begin{array}{c}\text { Measure of } \\
\text { correlation } \\
\text { (Cramer's V) }\end{array}$ & $\begin{array}{c}\text { Test's } \\
\text { value } \\
\chi^{2}\end{array}$ & $\begin{array}{l}\text { Signifi- } \\
\text { cance } \\
\mathrm{p}\end{array}$ & $\begin{array}{c}\text { Cramer's } \\
\text { V }\end{array}$ \\
\hline Telecommunication & \multicolumn{6}{|c|}{ Statistics are not calculated as the use of services has constant values. } \\
\hline $\begin{array}{l}\text { Those related to software and } \\
\text { IT consultancy }\end{array}$ & 7.63 & 0.022 & 0.195 & 0.660 & 0.417 & 0.057 \\
\hline Information & 9.419 & 0.009 & 0.216 & 7.247 & 0.007 & 0.190 \\
\hline Legal & 11.011 & 0.004 & 0.234 & 4.341 & 0.037 & 0.147 \\
\hline $\begin{array}{l}\text { Accounting and } \\
\text { bookkeeping/tax consulting }\end{array}$ & 6.530 & 0.038 & 0.180 & 0.648 & 0.421 & 0.057 \\
\hline $\begin{array}{l}\text { Consultancy related to } \\
\text { management/consulting }\end{array}$ & 10.603 & 0.005 & 0.230 & 13.143 & 0.000 & 0.256 \\
\hline In the field of $R \& D$ & 19.154 & 0.000 & 0.309 & 26.204 & 0.000 & 0.361 \\
\hline Advertising & 3.558 & 0.169 & 0.133 & 2.929 & 0.087 & 0.121 \\
\hline Market and opinion research & 13.376 & 0.001 & 0.258 & 12.232 & 0.000 & 0.247 \\
\hline Related to employment & 8.420 & 0.015 & 0.205 & 4.733 & 0.030 & 0.153 \\
\hline
\end{tabular}

Source: own research, 2014/2015. 
The identified dependencies are mostly characterised by statistical significance (Table 3). In case of the relationship between the use of business services and the enterprise's size, only in case of advertising services the dependency is not statistically significant, whereas in case of the dependency between the use of business services and the capital origin such a situation takes place besides advertising services, additionally also in case of the services related to software and computer science as well as accounting and bookkeeping services. In these four cases, the statistical significance exceeded the critical value $p=0.05$, what provides the basis to reject the hypothesis of the relationship between the variables. The strength of the identified statistical significant dependencies is not, however, too big - the value of the Cramer's V coefficient only twice exceeded the level of 0.3 (0.361 and 0.309 with the dependency between the use of R\&D and, respectively, the capital origin and the size of the enterprise).

\section{Assessment of the cooperation with the companies rendering business services performed by managers of enterprises in the sector of food processing industry}

The cooperation with the companies rendering business services in Poland is assessed very high. The mean of scores made on the scale from 1 to 4 formed itself at the level of 3.48. Characteristic is also minor differentiation in case of individual services - the spread of average scores was between 3.34 and 3.58 (Table 4). The best was assessed the cooperation with the companies rendering information services, the worst - those related to employment.

Table 4. Assessment of the cooperation with the companies rendering business services carried out by managers of the enterprises from the sector of food processing industry

\begin{tabular}{|c|c|c|c|c|c|c|c|c|c|c|c|c|}
\hline \multirow{3}{*}{ Services } & \multirow{2}{*}{\multicolumn{2}{|c|}{ Total }} & \multicolumn{6}{|c|}{ Size of the enterprise } & \multicolumn{4}{|c|}{ Capital origin } \\
\hline & & & \multicolumn{2}{|c|}{ Small } & \multicolumn{2}{|c|}{ Medium } & \multicolumn{2}{|c|}{ Large } & \multicolumn{2}{|c|}{ Purely Polish } & \multicolumn{2}{|c|}{$\begin{array}{l}\text { Foreign and } \\
\text { mixed }\end{array}$} \\
\hline & Mean & $\begin{array}{c}\text { St. } \\
\text { dev. }\end{array}$ & Mean & $\begin{array}{c}\text { St. } \\
\text { dev. }\end{array}$ & Mean & $\begin{array}{c}\text { St. } \\
\text { dev. }\end{array}$ & Mean & $\begin{array}{c}\text { St. } \\
\text { dev. }\end{array}$ & Mean & $\begin{array}{c}\text { St. } \\
\text { dev. }\end{array}$ & Mean & $\begin{array}{c}\text { St. } \\
\text { dev. }\end{array}$ \\
\hline Telecommu-nication & 3.41 & 0.52 & 3.22 & 0.49 & 3.44 & 0.50 & 3.46 & 0.54 & 3.42 & 0.51 & 3.40 & 0.57 \\
\hline $\begin{array}{l}\text { Those related to soft- } \\
\text { ware and IT } \\
\text { consultancy }\end{array}$ & 3.47 & 0.60 & 3.06 & 0.80 & 3.46 & 0.60 & 3.57 & 0.50 & 3.45 & 0.62 & 3.51 & 0.55 \\
\hline Information & 3.58 & 0.50 & 3.33 & 0.49 & 3.53 & 0.50 & 3.66 & 0.48 & 3.56 & 0.50 & 3.62 & 0.49 \\
\hline Legal & 3.52 & 0.52 & 3.29 & 0.59 & 3.55 & 0.50 & 3.55 & 0.50 & 3.56 & 0.52 & 3.41 & 0.50 \\
\hline $\begin{array}{l}\text { Accounting and book- } \\
\text { keeping/tax consulting }\end{array}$ & 3.51 & 0.50 & 3.39 & 0.50 & 3.46 & 0.50 & 3.59 & 0.50 & 3.54 & 0.50 & 3.43 & 0.50 \\
\hline $\begin{array}{l}\text { Consultancy related to } \\
\text { management/consulting }\end{array}$ & 3.46 & 0.55 & 3.00 & 0.00 & 3.44 & 0.51 & 3.52 & 0.59 & 3.45 & 0.55 & 3.47 & 0.57 \\
\hline In the field of $R \& D$ & 3.50 & 0.56 & 3.50 & 0.58 & 3.59 & 0.51 & 3.47 & 0.59 & 3.56 & 0.50 & 3.44 & 0.62 \\
\hline Advertising & 3.46 & 0.54 & 3.42 & 0.51 & 3.31 & 0.53 & 3.56 & 0.54 & 3.43 & 0.55 & 3.53 & 0.51 \\
\hline $\begin{array}{l}\text { Market and opinion } \\
\text { research }\end{array}$ & 3.53 & 0.50 & 3.50 & 0.58 & 3.36 & 0.50 & 3.59 & 0.50 & 3.48 & 0.51 & 3.59 & 0.50 \\
\hline Related to employment & 3.34 & 0.56 & 3.00 & 0.58 & 3.20 & 0.50 & 3.50 & 0.54 & 3.23 & 0.56 & 3.57 & 0.50 \\
\hline
\end{tabular}

Source: own research, 2014/2015. 
Table 5. Assessment of the statistical significance of differences in assessment of the cooperation with the companies rendering business services carried out by managers of the surveyed enterprises from the sector of food processing industry

\begin{tabular}{|c|c|c|c|c|c|c|}
\hline \multirow[b]{2}{*}{ Services } & \multicolumn{3}{|c|}{ Size of the enterprise $\mathrm{a}^{\mathrm{a}}$} & \multicolumn{3}{|c|}{ Capital origin $\square$} \\
\hline & $\begin{array}{c}\text { Test } \\
\text { statistics } \\
\mathrm{T}\end{array}$ & $\begin{array}{l}\text { Signi- } \\
\text { fican-ce }\end{array}$ & $\begin{array}{c}\text { Statistical } \\
\text { significance of } \\
\text { assessment } \\
\text { divergence }\end{array}$ & $\begin{array}{c}\text { Test } \\
\text { statistics } \\
\text { Z }\end{array}$ & $\begin{array}{l}\text { Signi- } \\
\text { fican-ce }\end{array}$ & $\begin{array}{c}\text { Statistical } \\
\text { significance of } \\
\text { assessment } \\
\text { divergence }\end{array}$ \\
\hline Telecommunication & 5.280 & 0.071 & No & -0.013 & 0.990 & No \\
\hline $\begin{array}{l}\text { Those related to software and } \\
\text { IT consultancy }\end{array}$ & 7.196 & 0.027 & Yes & -0.443 & 0.658 & No \\
\hline Information & 4.842 & 0.089 & No & -0.546 & 0.585 & No \\
\hline Legal & 2.965 & 0.227 & No & -1.632 & 0.103 & No \\
\hline $\begin{array}{l}\text { Accounting and book- } \\
\text { keeping/tax consulting }\end{array}$ & 3.624 & 0.163 & No & -1.211 & 0.226 & No \\
\hline $\begin{array}{l}\text { Consultancy related to } \\
\text { management/consulting }\end{array}$ & 4.982 & 0.083 & No & -0.138 & 0.890 & No \\
\hline In the field of R\&D & 0.439 & 0.803 & No & -0.689 & 0.491 & No \\
\hline Advertising & 4.961 & 0.084 & No & -0.835 & 0.404 & No \\
\hline Market and opinion research & 1.665 & 0.435 & No & -0.756 & 0.450 & No \\
\hline Related to employment & 10.199 & 0.006 & Yes & -2.613 & 0.009 & Yes \\
\hline
\end{tabular}

$\square$ - Mann-Whitney U test.

Source: own research, 2014/2015.

In the research, the authors also analysed the significance of differences between the scores relating to individual services depending on the enterprise's size and its capital origin (Table 5). The analyses carried out with the use of nonparametric tests: KruskalWallis ANOVA (for the first grouping variable) and Mann-Whitney U (for the second grouping variable) showed that the statistical significance of the differences between the scores took place only in three cases: twice as related to the variable characterising the size of the enterprise and once as related to the capital origin. In case of the enterprise's size, clear differences refer to the assessment of the cooperation with the companies rendering services related to software and IT consulting as well as the ones related to employment, whereas the capital origin significantly differentiated the assessment of the cooperation with the entities operating in the sphere of employment. In these cases, the asymptotic significance did not exceed the adopted critical value $\mathrm{p}=0.05$, what means that there are no grounds for rejection of the hypothesis of the existence of the statistically significant differences.

In their research, the authors identified the eight most important factors affecting the positive assessment of the cooperation (Table 6).

Of the greatest importance for respondents was reliability and integrity of the companies rendering business services - this factor was among the two most often mentioned one in case of the six amongst the nine analysed types of services, noting the percentages from $27.8 \%$ to $42.0 \%$. Four times among the two key factors appeared high quality of services and high competences of employees of the service companies. The latter factor recorded, at the same time, the highest percentage of indications amongst all the cases analysed $-45.8 \%$ of indications as related to services of management and consulting advice. Relatively of the lowest importance was the innovative nature of services as well as 
the service company's brand and image (which failed to appear at least once among the most important factors) as well as mutual trust (which appeared only once, but as the most important factor in case of the services related to employment).

Table 6. The factors crucial to the positive assessment of the cooperation with the companies rendering business services in the opinion of managers of the surveyed enterprises from the sector of food processing industry

\begin{tabular}{|c|c|c|c|c|c|c|c|c|}
\hline \multirow[b]{2}{*}{ Services } & \multicolumn{8}{|c|}{ Factors affecting the positive assessment of cooperation } \\
\hline & 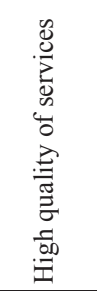 & 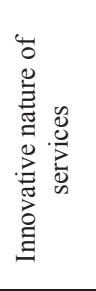 & 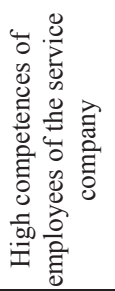 & 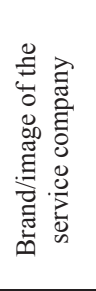 & 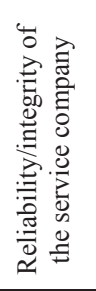 & 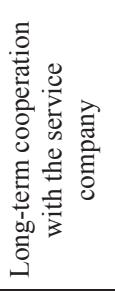 & 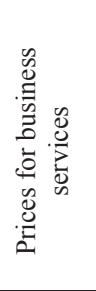 & 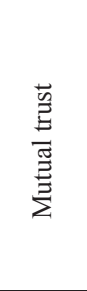 \\
\hline Telecommunication & $37.1 \%$ & $19.6 \%$ & $18.0 \%$ & $25.3 \%$ & $34.0 \%$ & $39.7 \%$ & $31.4 \%$ & $15.5 \%$ \\
\hline $\begin{array}{l}\text { Those related to software and IT } \\
\text { consultancy }\end{array}$ & $30.6 \%$ & $25.0 \%$ & $35.4 \%$ & $19.4 \%$ & $37.5 \%$ & $34.0 \%$ & $28.5 \%$ & $22.9 \%$ \\
\hline Information & $44.5 \%$ & $28.1 \%$ & $31.1 \%$ & $25.2 \%$ & $42.0 \%$ & $24.4 \%$ & $24.4 \%$ & $19.3 \%$ \\
\hline Legal & $33.6 \%$ & $8.2 \%$ & $36.6 \%$ & $17.9 \%$ & $40.3 \%$ & $35.1 \%$ & $16.4 \%$ & $33.6 \%$ \\
\hline $\begin{array}{l}\text { Accounting and } \\
\text { bookkeeping/tax consulting }\end{array}$ & $41.8 \%$ & $13.0 \%$ & $36.3 \%$ & $15.8 \%$ & $32.2 \%$ & $35.6 \%$ & $21.9 \%$ & $32.9 \%$ \\
\hline $\begin{array}{l}\text { Consultancy related to } \\
\text { management/consulting }\end{array}$ & $23.6 \%$ & $18.1 \%$ & $45.8 \%$ & $15.3 \%$ & $27.8 \%$ & $29.2 \%$ & $34.7 \%$ & $30.6 \%$ \\
\hline In the field of R\&D & $43.8 \%$ & $34.4 \%$ & $25.0 \%$ & $17.2 \%$ & $39.1 \%$ & $31.3 \%$ & $17.2 \%$ & $20.3 \%$ \\
\hline Advertising & $31.2 \%$ & $23.9 \%$ & $29.4 \%$ & $15.6 \%$ & $36.7 \%$ & $21.1 \%$ & $40.4 \%$ & $25.7 \%$ \\
\hline Market and opinion research & $24.5 \%$ & $22.4 \%$ & $26.5 \%$ & $26.5 \%$ & $36.7 \%$ & $28.6 \%$ & $26.5 \%$ & $24.5 \%$ \\
\hline Related to employment & $18.6 \%$ & $14.0 \%$ & $31.4 \%$ & $18.6 \%$ & $30.2 \%$ & $34.9 \%$ & $36.0 \%$ & $40.7 \%$ \\
\hline
\end{tabular}

Source: own research, 2014/2015.

\section{Discussion and conclusions}

The presented research findings indicate a broad scale of the use by enterprises of the sector of food processing industry of business services. They are treated as an important factor determining their functioning in the market and raising their competitiveness. The aim of the paper is to analyse the level of making use of business services by the enterprises operating in the food processing industry as well as to assess the cooperation between the companies rendering such services.

Referring to the first of the asked research questions, relating to the assessment whether the use of business services depends on of the enterprise's size and capital origin, we can answer in a positive way. There is a positive relationship between the features of enterprises and the use of business services - the bigger they are and the more connected with foreign capital, the most often they use of the majority of business services. Lack of such relationship occurs sporadically and the specific case is here advertising services whose use is not determined by whatever of the analysed features of enterprises. This way, the hypotheses $\mathrm{H} 1$ and $\mathrm{H} 2$ concerning the occurrence of statistical dependence between the 
size and origin of the capital of enterprises and the evaluation of cooperation with companies providing business services.

Answering the second research question referring to the impact of the enterprise's size and capital origin on the differentiation of assessment of the cooperation with the companies rendering business services it is proper to note that the assessment of cooperation with the companies rendering business services is not in principle determined either by the enterprise's size or by the share of foreign capital. Such an impact was revealed only in three cases. The relationships primarily concern the assessment of cooperation with the companies rendering the services related to employment - the bigger are the firms making use of them and of the greater importance for their functioning is foreign capital, the better is their assessment of such cooperation. This also means that the hypotheses $\mathrm{H} 3$ and $\mathrm{H} 4$ regarding statistical independence between the size and origin of the capital of enterprises and evaluations of cooperation with companies providing business services.

Considering the companies of a food processing sector it is recommended to increase the scale of the use of business services, especially with regard to entities from the SME sector. On the other hand, the companies providing business services should focus on the quality of services, in particular on the efficiency and reliability of relationships with contractors and they should pay attention to high competences of workers - since these are factors which affect a positive evaluation of the cooperation and customer satisfaction to the largest extent.

The presented considerations do not use up the issues of cooperation between companies rendering business services and their customers. They can be a starting point for a further, deeper research. A crucial problem is, for instance, identification of the reasons for non-enjoyment of business services by a part of enterprises operating in the market as well as the lip service of some findings, e.g. those related to the factors affecting the assessment of cooperation. The quantitative research explaining these doubts should be conducted on a considerably bigger sample supporting it with a qualitative research of the exploratory nature.

\section{References}

Chilimoniuk-Przeździecka, E. (2011). Eksport usług biznesowych z Polski (Export of Business Services from Poland). Zeszyty Naukowe UE w Poznaniu, 179, 45-56.

Czakon, W. (2005). Ku systemowej teorii przewagi konkurencyjnej przedsiębiorstwa (Towards the System Theory of Competitive Edge of an Enterprise). Przeglad Organizacji, 5, 5-8.

Daszkowska, M. (1998). Usługi. Produkcja, rynek, marketing (Services. Production, Market, Marketing). Wydawnictwo Naukowe PWN, Warszawa.

Dąbrowska, A. (2008). Rozwój rynku usług w Polsce - uwarunkowania i perspektywy (Development of the Market for Services in Poland. Determinants and Perspectives). SGH, Warszawa.

De Vaan, M. (2014). Interfirm Networks in Periods of Technological Turbulence and Stability. Research Policy, 43(10), 1666-1680.

Dyer, J.H., Singh, H. (1998). The Relational View: Cooperative Strategy and Sources of Interorganizational Competitive Advantage. Academy of Management Review, 23(4), 660-679.

Gralpois, B., Liodice, B. (2010). Agency mania: harness the madness of client/agency relationships for highimpact results, SelectBooks, New York.

Klimas, P. (2015). Relacje współtworzenia - propozycja konceptualizacji (Relationships of Contributing. Proposal for Conceptualisation). Marketing $i$ Rynek, 9, 219-228. 
Kox, H.L.M., Rubalcaba, L. (2007). Analysing the Contribution of Business Services to European Economic Growth. Bruges European Economic Research Papers, 9, 1-57.

Krupski, R. (2015). Relacje niesformalizowane w badaniach empirycznych (Non-formalised Relationships in Empirical Studies). Prace Naukowe Wałbrzyskiej Wyższej Szkoły Zarzqdzania i Przedsiębiorczości, 32, $17-30$.

Kuczewska, L. (2009). Stan i struktura usług biznesowych w Polsce (State and Structure of Business Services in Poland). Handel Wewnętrzny, 1, 1-8.

Kuczewska, L., Nowacki, R. (2016). Innowacyjność usług biznesowych w podnoszeniu konkurencyjności przedsiębiorstw (Innovativeness of Business Services in Raising Enterprise Competitiveness). PWE, Warszawa.

Leszczyński, G. (2012). Dopasowanie a sprzedaż w relacjach businsess-to-business z perspektywy przedsiębiorstw produkcyjnych (Matching and Sale in Business-to-Business Relations from the Perspective of Manufacturing Enterprises). W: G. Leszczyński, B. Pilarczyk (red.), Relacje na rynku business-to-business. Rozwój. Wartość. Komunikacja (Relationships in the Business-to-Business Market, Development. Value. Communication). Wydawnictwo Uniwersytetu Ekonomicznego, Poznań, 80-82.

Majchrzak, M. (2012). Konkurencyjność przedsiebiorstw podsektora usług biznesowych w Polsce. Perspektywa mikro-, mezo- i makroekonomiczna (Competitiveness of Enterprises of the Sub-sector of Business Services in Poland. Micro-, Mezo- and Macroeconomic Perspective). CeDeWu, Warszawa.

Niemczyk, J. (2015). Poziomy rozwoju sieci międzyorganizacyjnej (Level of Development of the Interorganisational Network). Prace Naukowe Wałbrzyskiej Wyższej Szkoly Zarzqdzania $i$ Przedsiębiorczości, 32, 243-251.

Nowacki, R. (2009). Rozwój usług marketingowych w Polsce a ich jakość (Development of Marketing Services in Poland and Their Quality). Handel Wewnętrzny, 2, 18-28.

Nowacki, R. (2016). Innowacyjność usług marketingowych a ich użyteczność w procesach zarządzania przedsiębiorstwem (Innovativeness of Marketing Services and Their Usefulness in the Processes of Enterprise Management). Nierówności Społeczne a Wzrost Gospodarczy, 45, 204-213.

Przemysł - wyniki działalności w 2017 roku (Industry. Results of Activities in 2017), (2018), GUS, Warszawa.

Ritter, T. (1999). The Networking Company. Antecedents for Coping with Relationships and Networks Effectively. Industrial Marketing Management, Vol. 28, 467-479.

Ritter, T., Wilkinson, I.F., Johnston, W.J. (2004) Managing in Complex Business Networks. Industrial Marketing Management, 33(3), 175-183.

Rogoziński, K. (2000). Usługi rynkowe (Market Services), Akademia Ekonomiczna w Poznaniu, Poznań 2000

Rogoziński, K. (2006). Wpisanie relacji w marketingowy kontekst (Putting Relationships in the Marketing Context). W: K. Rogoziński (red.), Zarządzanie relacjami w usługach (Relationships Management in Services), Difin, Warszawa, 13-14.

Rynek Wewnetrzny w 1996 roku (Internal Market in 1996). (1997) GUS, Warszawa.

Rynek Wewnętrzny w 2014 roku (Internal Market in 2014). (2015) GUS, Warszawa.

Stańczyk-Hugiet, E., Strzelecka, R. (2015). Relacje strategiczne przedsiębiorstw deweloperskich (Strategic Relationships of Developer Enterprises). Problemy Zarzadzania, 1(50), 68-87.

Szczukocka, A. (2012). Wpływ usług biznesowych na rozwój gospodarki (Impact of Business Services on the Economy Development). Zeszyty Naukowe Uniwersytetu Szczecińskiego, 736, Finanse, Rynki Finansowe, Ubezpieczenia, 55, 165-166.

The Contribution of Business Services to Industrial Performance. A Common Policy Framework. Commission of the European Communities, Brussels 1998 COM (1998). 534 final, Communication from the Commission to the Council.

Usługi biznesowe (Business Services), (2018), GUS, Warszawa.

Zieliński, M. (2014). Siła w relacjach biznesowych (Strength in Business Relationships). W: Zarządzanie relacjami w biznesie. Współczesne wyzwania (Relationships Management in Business. Contemporary Challenges). Studia Ekonomiczne. Zeszyty Naukowe Uniwersytetu Ekonomicznego w Katowicach, 182, 6575 .

For citation:

Nowacki R., Wasilik K. (2018). Cooperation of Enterprises of the Sector of Food Processing Industry with the Entities Rendering Business Services. Problems of World Agriculture, 18(4), 359-369; DOI: $10.22630 /$ PRS.2018.18.4.125 